UK energy research

\section{Powers link up with SERC}

BRITAIN'S Science and Engineering Research Council (SERC) was cock-ahoop this week about a three-year agreement with the nationalized energy corporations - the Central Electricity Generating Board (CEGB), the British Gas Corporation and the National Coal Board - to support energy research in universities and polytechnics. The deal between these often warring organizations has taken two years to work out, and even now the bodies will keep each other at arm's length: there will be three separate "joint panels", one between each industry and SERC, to assess projects.

The sum involved is between $£ 600,000$ and $£ 750,000$, or up to $£ 250,000$ per industry per year, half of which will come from the energy corporations and half from SERC. However, at least in the first year, there is to be no new money, just a reallocation of existing support. So the scheme is seen at SERC as only a beginning, a "token of commitment" between the partners. On the council's side, the immediate interest is to maintain the academic quality of corporationsupported research - and only ultimately to raise more money. On the side of the energy corporations, there is interest in influencing, in some degree, the directions of research council policy.

Of the three corporations, CEGB is pushing ahead fastest - and has already placed four grants through the new scheme with the universities of Aston, Reading and Loughborough and with Imperial College, London. One of CEGB's interests is "a long-term dialogue with SERC", At present the board spends some $£ 500,000$ each year directly in the universities, of which $£ 50,000$ will this year go through the SERC link, to be matched in equal amount by SERC. This is about half the $£ 200,000$ $£ 250,000$ per industry per year projected by SERC, but CEGB says its total "may rise to that in future years".

SERC's contribution to the scheme will come out of its present energy-related research spending of about $£ 4.5$ million a year, which goes to subjects from fusion to materials science and heat pumps. Of this, £1.7 million is channelled through its energy committee, which will have to find the money for the new agreement. The council will respond to the research priorities of the energy corporations, which will have free choice of what projects to support, subject only to the advice of the three joint SERC-industry panels. The boards have a list of priorities which may seem long-term to them but which has a definite short-term flavour by SERC standards. Thus other SERC energy research is likely to be squeezed unless new money is generated.

Robert Walgate
US/Romanian relations

\section{Move to stay in favour}

THE threat by the United States to refuse most favoured nation status to Romania when the current agreement expired at the end of June was averted by what amounted to a personal assurance from President Nicolae Ceaucescu to President Reagan: the new law demanding the repayment of higher education costs by those wishing to leave the country would not now be implemented.

A US law from 1974 specifically forbids the granting of most favoured nation status to countries which impose such a restriction on their graduates. The Romanian Government has maintained that the new regulations, which affect mainly Romania's German and Jewish minorities, did not imply ethnic discrimination, but were simply a matter of economics Romania could not afford to invest in educating experts who would then give their skills to other, richer countries.

Since the fees had to be repaid in hard currency, which Romanian citizens are forbidden to possess, it was clear that their costs would have to be met by friends and relatives abroad. The West German Government, while unwilling to meet the education tax as such, has worked out a scheme of "financial incentives" so that the German emigrants will be exempt although it refuses to comment on rumours

that it is increasing the DM 5,000 at present paid on each German emigrant to around DM 8,000, so that the Romanians will not be out of pocket. Although Israel offered no such incentives, by mid-April a number of Israeli diplomats were confident that the repayment scheme would not be fully implemented.

At the end of May, the Romanian foreign minister Stefan Andrei visited Washington, apparently carrying President Ceaucescu's assurance that the scheme would be dropped. Although Romanian susceptibilities were offended when Mr Edward Derwinski of the State Department publicly called it a "major retreat" by the Romanians, the assurances apparently stood, and the US Government advised Congress to renew most favoured nation status for another term.

Although the US Government pressed for the law to be repealed, it is not clear whether this has been done, or whether it will simply not be endorsed. In the latter case, there would be doubts as to how much reliance can be placed on the Romanian assurances - during 1982, virtually until the law demanding repayment for education was passed on 6 November, President Ceaucescu was assuring Western diplomats that no such law was being prepared.

\title{
The nuclear power game in the year 2000
}

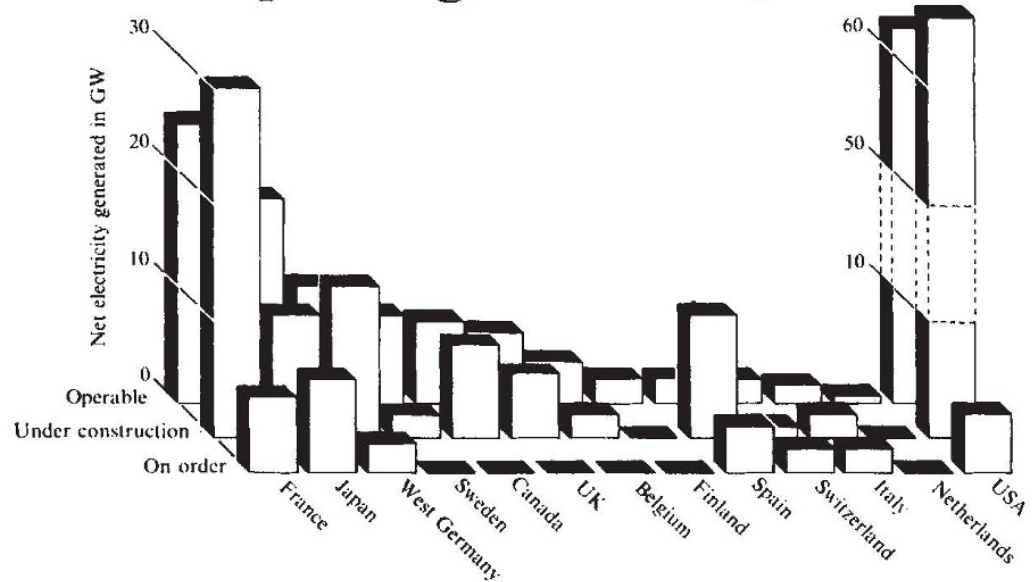

THE United States dominates the countries of the Organization for Economic Cooperation and Development (OECD) in terms of the net amount of electricity generated by nuclear power, producing more than twice as much nuclear-generated electricity as its closest rival, France. However, despite this massive nuclear production, the United States is well down the nuclear table in percentage terms, producing only 12.6 per cent of its electricity in 1982 through nuclear power. This compares with 40.3 per cent in Finland, 38.7 per cent in France and Sweden and 30.2 per cent in Belgium. The corresponding figure in the United Kingdom is only 16.4 per cent. The percentage figures for the year 2000 should show the effects of massive nuclear development programmes taking place in France and Spain, with France producing as much as 80 per cent of its electricity through nuclear power and Spain running in second place with 49.4 per cent of its electricity produced through nuclear power. In comparison, the United States is expected to produce 19.8 per cent and Britain 36.6 per cent "nuclear" electricity. Source: Summary of Nuclear Power and Fuel Cycle Data in OECD Member Countries, OECD, Paris.
Melanie Kee 